\title{
THE SULPHANILAMIDE TREATMENT OF SCARLET FEVER
}

\author{
By JANE O. FRENCH, M.D., D.P.H., D.C.O.G. \\ Assistant Medical Officer, City of Coventry Public Health Department, \\ Late Resident Assistant Physician, Ruchill Fever Hospital, Glasgow
}

IT is now more than four years since Domagk discovered and patented "Prontosil". A very large amount of experimental and clinical evidence has accumulated since then to show the value of this substance and its derivatives in a variety of infections, mainly streptococcal. It is not intended here to discuss any of these findings, but it may be broadly stated that the sulphanilamide drugs have found a place in the treatment of certain streptococcal infections, chiefly puerperal infections, erysipelas, and streptococcal meningitis. During the time that has elapsed since sulphanilamide and allied compounds came into general use it has also become evident that in certain cases they exercise a toxic action, and a fatal issue has, upon occasion, followed their use.

It was only natural that a class of drugs proved to have such interesting effects on streptococcal infections should be given a trial in scarlet fever. However, very few reports have as yet appeared regarding the value of the sulphanilamide compounds in this disease.

Peters \& Havard (1937) reported favourably upon the effect of benzylsulphanilamide in scarlet fever. In a series of 300 cases they found a lowered complication rate in their treated cases as compared with the controls. The maximum total dose given was $22.5 \mathrm{~g}$. over a period of 6 days. Scarlet fever antitoxin was given only to a few cases in the control group.

Hogarth (1937) published his experience with benzyl-sulphanilamide in a controlled series of 356 cases of scarlet fever. One-third of the patients received no specific treatment, one-third received benzyl-sulphanilamide in the dose about to be stated, and one-third received the same dose of benzyl-sulphanilamide and also scarlet fever antitoxin. The maximum total dose was $15.5 \mathrm{~g}$., and the drug was given during the first and third weeks of illness. This author found that the drug had no significant effect upon the initial toxaemia, or upon the complication rate.

In America, Sako, Dwan \& Platou (1938) reported favourably upon the value of sulphanilamide in a series of 200 cases of scarlet fever, the complication rate in their treated cases being $8 \%$, in the untreated $41 \%$. The criteria for evaluating these results are, however, open to some criticism. The average duration of treatment was 12 days, and the average dose was $0.03 \mathrm{~g}$. per pound of body weight in $24 \mathrm{hr}$.

Long \& Bliss (1937), Basman \& Perley (1937), McIntosh, Wilcox \& Wright (1937), Mitchell \& Trachsler (1937), and Hageman \& Blake (1938) all reported 
upon small numbers of cases of scarlet fever treated with sulphanilamide. Their opinions as to its value are conflicting. In America also, Patterson (1937) reported favourably on the use of "Prontosil" in the treatment of 200 cases of scarlet fever. This is a large number, but the author unfortunately gives so few details about the cases that his observations and conclusions, as recorded, make no contribution to the scientific literature on the subject. Anderson, speaking at a meeting of the Society of Medical Officers of Health in February 1939 , reported that in a controlled series of cases, those treated with "Prontosil" and antitoxin showed better results than all others, but that "Prontosil" alone gave poor results.

The total amount of information on the effect of sulphanilamide in scarlet fever is small, and the reports are not very encouraging. They appear to indicate that sulphanilamide alone is ineffective in the treatment of the disease, and, as Peters \& Havard (1937) suggested, "possibly a combination of drug and serum would be more effective". Hogarth's work does not suggest that this is so, but the number of cases he treated with sulphanilamide and serum was not large. It must also be borne in mind that the dose of sulphanilamide employed by all the workers, to whose experiments reference has been made, was small, and treatment was not continued for very long. So far, also, benzylsulphanilamide seems to have been the drug most used in the treatment of scarlet fever, and in Britain no reports of sulphanilamide treatment in this disease have as yet been published. It therefore appeared to be desirable that a large series of cases should be given larger doses over a longer period, and that these cases should also be treated with serum. When this had been done and the results very carefully observed and assessed, an authoritative statement might be made on the value of the sulphanilamide class of drugs in scarlet fever. The investigation about to be described was carried out on the lines suggested by Peters \& Havard, and may, perhaps, help in the elucidation of this important problem. The experiment was carefully controlled and its objects were (i) to find the therapeutic effect of sulphanilamide in scarlet fever, and (ii) to observe any toxic reactions due to the drug.

\section{Plan of investigation}

This investigation relates to 340 cases of scarlet fever treated at Ruchill Fever Hospital, Glasgow. 170 cases were treated with sulphanilamide and 170 cases were not so treated. The investigation, covering a period of 5 months in all, has been divided into two parts, the first consisting of cases admitted in the months of July and August 1937, and the second of cases admitted in the months of January, February, and March 1938. By this division, any variation in severity that might have been attributed to season was avoided. The cases were under the author's clinical care throughout. The method of allocation to the sulphanilamide group and the control group was strictly by order of admission to hospital, irrespective of any other factor whatsoever. The general medical treatment of all cases was the same. Scarlet fever antitoxin was given 
on admission to any patient who was thought to require it, irrespective of whether that patient was going to have sulphanilamide or not. Out of the total 340 cases $269=79 \cdot 1 \%$ received serum. Of these 135 were in the sulphanilamide group, and 134 in the control group. The average dose was 20 c.c.

\section{The SUlPhaNiLAMIDE TREATMENT}

The drugs used were sulphanilamide (para-amino-benzene-sulphonamide) and benzyl-sulphanilamide (para-benzyl-amino-benzene-sulphonamide). The total number of patients who received the former was 108, of the latter 62 . The administration of the drugs was begun immediately after admission to hospital. Sulphanilamide was given in powder form, benzyl-sulphanilamide in tablet form. The ordinary hospital dietary was used, unmodified to suit special requirements, as onions are not included and eggs given only in very small quantity.

\section{The DOSE OF SUlPhanilamide}

At the time that this investigation was begun there was very little available information as to what would prove a suitable dose of sulphanilamide in scarlet fever. It was decided therefore to employ a large dose and to continue treatment during the entire period of 4 weeks which constituted the average period of detention in hospital of cases of scarlet fever. The dose given was as follows:

(a) Patients 5 years of age and over received $1 \mathrm{~g} .4$ hourly for the first 14 days in hospital, thereafter $1 \mathrm{~g}$. thrice daily for 14 days (or until dismissal if that event occurred before the 28th day in hospital. The day of admission was counted the first day). Total average dose was $112 \mathrm{~g}$.

(b) Patients under 5 years of age received 0.5 g. 4 hourly for the first 14 days in hospital, thereafter $0.5 \mathrm{~g}$. thrice daily for 14 days. Total average dose was $56 \mathrm{~g}$.

It may be argued that it would have been a wiser policy to have given the larger doses later in the illness, during the time that complications are more likely to occur. Experience, however, has convinced me that the vast, majority of complications arise within the first 2 weeks of illness, and, indeed, that many of them are present on admission, so that the policy of giving larger doses first appeared a sound one.

The cases were all seen by me on the day of admission, so that their severity was assessed before treatment had any effect. A special case-sheet was used, and on it the salient features were recorded, a particular note being made of complications present on admission, as this is an important point, with which other writers on the subject have not dealt. The cases were seen daily thereafter, and the time of disappearance of the rash, throat exudate, and complications present on admission was noted, and in addition the time of appearance and disappearance of complications developing after admission. 
COMPARISON OF SULPHANILAMIDE GROUP AND CONTROL GROUP

The following table shows that there was an even distribution in respect of age, sex, severity of illness, and complications in the two groups.

\section{Table I}

(1) Age and sex incidence

\begin{tabular}{|c|c|c|c|c|c|c|c|c|}
\hline \multirow{3}{*}{$\begin{array}{l}\text { Age in } \\
\text { years }\end{array}$} & \multicolumn{4}{|c|}{ Sulphanilamide group } & \multicolumn{4}{|c|}{ Control group } \\
\hline & \multicolumn{2}{|c|}{ Males } & \multicolumn{2}{|c|}{ Females } & \multicolumn{2}{|c|}{ Males } & \multicolumn{2}{|c|}{ Females } \\
\hline & No. & $\%$ & No. & $\%$ & No. & $\%$ & No. & $\%$ \\
\hline $0-5$ & 33 & $52 \cdot 3$ & 42 & $39 \cdot 2$ & 40 & $57 \cdot 2$ & 41 & $41 \cdot 0$ \\
\hline $6-10$ & 17 & 26.9 & 38 & $35 \cdot 4$ & 15 & $21 \cdot 4$ & 41 & $41 \cdot 0$ \\
\hline $11-15$ & 5 & $7 \cdot 8$ & 12 & $11 \cdot 2$ & 7 & 10.0 & 6 & $6 \cdot 0$ \\
\hline $16-20$ & 4 & $1 \cdot 5$ & 5 & $4 \cdot 8$ & 4 & $5 \cdot 7$ & 5 & $5 \cdot 0$ \\
\hline Over 20 & 4 & 1.5 & 10 & $9 \cdot 4$ & 4 & $5 \cdot 7$ & 7 & $7 \cdot 0$ \\
\hline All ages & 63 & $37 \cdot 0$ & 107 & 63.0 & 70 & $41 \cdot 2$ & 100 & $58 \cdot 8$ \\
\hline
\end{tabular}

(2) Duration of illness (in days) before admission to hospital

\begin{tabular}{|c|c|c|c|c|}
\hline \multirow[b]{3}{*}{$\begin{aligned} \text { Cases admitted: 1st and 2nd days } \\
\text { 3rd day or later }\end{aligned}$} & \multicolumn{2}{|c|}{ Sulphanilamide group } & \multicolumn{2}{|c|}{ Control group } \\
\hline & No. & $\%$ & No. & $\%$ \\
\hline & $\begin{array}{l}94 \\
76\end{array}$ & $\begin{array}{l}55 \cdot 2 \\
\mathbf{4 4} \cdot 8\end{array}$ & $\begin{array}{l}77 \\
93\end{array}$ & $\begin{array}{l}45 \cdot 2 \\
54 \cdot 8\end{array}$ \\
\hline $\begin{array}{l}\text { Average day of illness when admitted: } \\
\text { Mean } \\
\text { Mode }\end{array}$ & & & & \\
\hline
\end{tabular}

(3) Severity of infection

Mild

Moderate

Severe

$\overbrace{\begin{array}{rc}\text { No. } & \% \\ 90 & 52 \cdot 9 \\ 66 & 38 \cdot 9 \\ 14 & 8 \cdot 2\end{array}}^{\text {Sulphanilamide group }}$

$\begin{array}{cc}\text { Control group } \\ \text { No. } & \% \\ 87 & 51 \cdot 7 \\ 68 & 40 \cdot 0 \\ 15 & 8 \cdot 3\end{array}$

(4) The condition of the throat

\begin{tabular}{|c|c|c|c|c|}
\hline & \multicolumn{2}{|c|}{ Sulphanilamide group } & \multicolumn{2}{|c|}{ Control group } \\
\hline & No. & $\%$ & No. & $\%$ \\
\hline Clean & 83 & $48 \cdot 9$ & 87 & $51 \cdot 1$ \\
\hline $\begin{array}{l}\text { Spotted } \\
\text { Patched }\end{array}$ & $\begin{array}{l}26 \\
61\end{array}$ & $\begin{array}{l}15 \cdot 1 \\
36 \cdot 0\end{array}$ & $\begin{array}{l}20 \\
63\end{array}$ & $\begin{array}{l}11 \cdot 8 \\
27 \cdot 1\end{array}$ \\
\hline
\end{tabular}

(5) Complications present on admission

In many individuals there was more than one complication present on admission.

\begin{tabular}{|c|c|c|c|c|}
\hline \multirow[b]{3}{*}{ Cervical adenitis } & \multicolumn{2}{|c|}{ Sulphanilamide group } & \multicolumn{2}{|c|}{ Control group } \\
\hline & No. & $\%$ & No. & $\%$ \\
\hline & 108 & 63.5 & 96 & $56 \cdot 4$ \\
\hline Rhinitis & 32 & 18.8 & 31 & $19 \cdot 3$ \\
\hline Otitis media & 1 & 0.5 & 5 & $2 \cdot 9$ \\
\hline Albuminuria & 3 & 1.7 & 3 & 1.9 \\
\hline Other & 26 & $15 \cdot 3$ & 24 & $14 \cdot 1$ \\
\hline
\end{tabular}




\section{THE EFFECT OF THE SULPHANILAMIDE TREATMENT}

The points wherein a new method of treatment might be expected to show its efficacy will now be considered, and the results in the two groups in respect of these factors will be compared and discussed.

\section{(1) The fading of the rash}

It is now generally admitted (Okell, 1932), that the rash of scarlet fever is a manifestation of a circulating toxin, commonly called the erythrogenic or Dick Toxin. Scarlet fever antitoxin, being prepared by the immunization of horses with this specific toxin, is a specific antibody for the toxin. Since most of the cases in this investigation were treated with serum, it was scarcely to be expected that any great improvement in hastening the fading of the rash would result from the addition of sulphanilamide in treatment. Table II shows that sulphanilamide had no effect in hastening the fading of the rash. This does not support the contention of Osgood \& Brownlie (1938), who, endeavouring to find the precise mode of action of sulphanilamide, concluded that "the major action of sulphanilamide on B-haemolytic streptococci seems to be the neutralization of toxins".

\section{Table II. The fading of the rash}

\begin{tabular}{|c|c|c|c|c|c|c|c|}
\hline \multirow{2}{*}{$\begin{array}{l}\text { Day of } \\
\text { illness } \\
\text { on which } \\
\text { admitted }\end{array}$} & \multicolumn{6}{|c|}{ Rash faded in days after admission } & \multirow[b]{2}{*}{ Total } \\
\hline & 1 & 2 & 3 & 4 & 5 & $\begin{array}{c}\text { No } \\
\text { rash }\end{array}$ & \\
\hline \multicolumn{8}{|c|}{ Sulphanilamide group } \\
\hline 1 & 10 & 5 & 2 & 1 & - & - & 18 \\
\hline 2 & 36 & 19 & 3 & - & - & 1 & 59 \\
\hline 3 & 36 & 19 & 8 & - & - & 2 & 65 \\
\hline 4 & 7 & 8 & 1 & - & - & - & 16 \\
\hline & 3 & 2 & - & 1 & - & - & 6 \\
\hline Later than 5 & 4 & 1 & - & - & - & 1 & 6 \\
\hline All days & 96 & 54 & 14 & 2 & - & 4 & 170 \\
\hline \multicolumn{8}{|c|}{ Control group } \\
\hline 1 & 11 & 7 & 1 & - & - & - & 19 \\
\hline 2 & 50 & 20 & 5 & - & - & - & 75 \\
\hline 3 & 20 & 17 & 5 & - & 1 & - & 43 \\
\hline 4 & 12 & 11 & 2 & - & - & - & 25 \\
\hline $\begin{array}{l} \pm \\
5\end{array}$ & 1 & 4 & - & - & 1 & - & 6 \\
\hline Later than 5 & - & 1 & - & - & - & 1 & 2 \\
\hline All days & 94 & 60 & 13 & - & 2 & 1 & 170 \\
\hline
\end{tabular}

\section{(2) The duration of primary pyrexia}

The primary pyrexia of scarlet fever may be taken as an index of the combined effect of $(a)$ toxaemia, $(b)$ the presence of a tonsillitis, $(c)$ the presence, in certain cases, of early complications. It might be expected, therefore, that sulphanilamide would secure an earlier cessation of primary pyrexia. This, however, it did not achieve. 
Table III. Duration in days of primary pyrexia

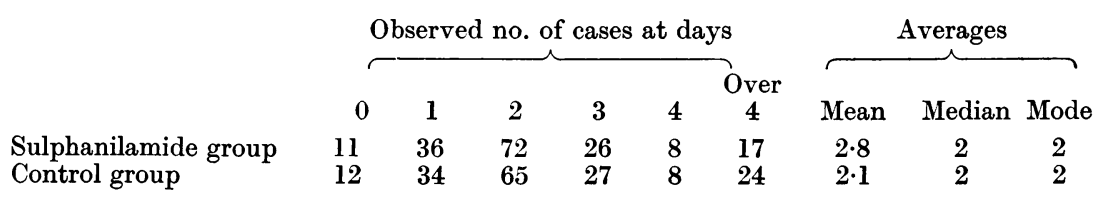

(3) The number of days in hospital

The duration of patients' residence in hospital in scarlet fever is dependent to a large extent on the presence or absence of complications. It might, therefore, be expected that a successful new method of treatment would show its efficacy, inter alia, by reducing the number of patients remaining in hospital longer than the statutory detention period of 28 days. The figures, in respect of the period of detention in hospital for the two treatment groups, show that sulphanilamide has no influence in curtailing the necessary period of hospitalization in scarlet fever, and none in reducing the number of patients remaining in hospital after the 28th day.

Table IV. The number of days in hospital

\begin{tabular}{|c|c|c|c|c|c|c|}
\hline \multirow{2}{*}{$\begin{array}{l}\text { No. of days } \\
\text { in hospital }\end{array}$} & \multicolumn{2}{|c|}{ Sulphanilamide group } & \multicolumn{2}{|c|}{ Control group } & \multirow{2}{*}{$\begin{array}{l}\text { Difference } \\
\quad \%\end{array}$} & \multirow{2}{*}{$\begin{array}{l}\text { Standard } \\
\text { error of } \\
\text { difference }\end{array}$} \\
\hline & No. & $\%$ & No. & $\%$ & & \\
\hline 28 or less & 123 & $72 \cdot 4$ & 122 & $71 \cdot 8$ & 一 & - \\
\hline $\begin{array}{l}29-35 \\
36-42 \\
43 \text { or more }\end{array}$ & $\begin{array}{l}23 \\
14 \\
10\end{array}$ & $\begin{array}{r}13 \cdot 5 \\
8 \cdot 2 \\
5 \cdot 8\end{array}$ & $\begin{array}{r}29 \\
11 \\
8\end{array}$ & $\begin{array}{r}17 \cdot 0 \\
6 \cdot 4 \\
4 \cdot 7\end{array}$ & $\begin{array}{l}3 \cdot 5 \\
-\end{array}$ & $\begin{array}{c}3 \cdot 170 \\
-\end{array}$ \\
\hline Total over 28 & 47 & $27 \cdot 6$ & 48 & $28 \cdot 2$ & - & - \\
\hline
\end{tabular}

Table V. Average duration in days of patients' residence in hospital

$\begin{array}{lcc} & \begin{array}{c}\text { Sulphanilamide } \\ \text { group }\end{array} & \begin{array}{c}\text { Control } \\ \text { group }\end{array} \\ \text { Mean duration } & 28 \cdot 3 & 28 \cdot 9 \\ \text { Median duration } & 26 & 26 \\ \text { Mode duration } & 26 & 25\end{array}$

(4) The incidence of complications

It was hoped that sulphanilamide would prove a useful adjunct in the therapy of scarlet fever by reducing the incidence of complications, as it had done in the cases reported by Peters \& Havard (1937), and by others since then. No statistically significant reduction in the complication rate manifested itself. The total complication rate for all cases was high, but in this connexion it may be stated that complications were very carefully sought for in this investigation and it is improbable that even the slightest escaped notice and recording. The total incidence of complications is shown in Tables VI and VII. 


\section{Table VI. Complications}

1. Total complicated cases

2. Total excluding those with early cervical adenitis only

3. Cases with complications present on admission

4. Cases in which complications developed after admission only

5. Cases in which complications were present on admission and also developed after admission

6. Total cases in which complications developed after admission
Sulphanilamide Control

\begin{tabular}{|c|c|c|c|c|c|}
\hline \multicolumn{2}{|c|}{ group } & \multicolumn{2}{|c|}{ group } & \multirow{2}{*}{$\begin{array}{c}\text { Difference } \\
\%\end{array}$} & \multirow{2}{*}{$\begin{array}{l}\text { Standard } \\
\text { error of } \\
\text { difference }\end{array}$} \\
\hline No. & $\%$ & No. & $\%$ & & \\
\hline 148 & $87 \cdot 1$ & 140 & $86 \cdot 4$ & 0.7 & - \\
\hline 106 & $63 \cdot 7$ & 100 & $58 \cdot 9$ & $4 \cdot 8$ & $5 \cdot 458$ \\
\hline 117 & $68 \cdot 8$ & 104 & $61 \cdot 1$ & $7 \cdot 7$ & $5 \cdot 400$ \\
\hline 31 & $18 \cdot 2$ & 36 & $21 \cdot 1$ & $2 \cdot 9$ & $4 \cdot 276$ \\
\hline 42 & $24 \cdot 2$ & 30 & $17 \cdot 6$ & $7 \cdot 1$ & $4 \cdot 401$ \\
\hline 73 & $42 \cdot 9$ & 66 & 38.7 & $4 \cdot 2$ & $4 \cdot 867$ \\
\hline
\end{tabular}

Table VII. The incidence of individual complications developing after admission to hospital

\begin{tabular}{|c|c|c|c|c|c|}
\hline \multicolumn{2}{|c|}{$\begin{array}{l}\text { Sulphanilamide } \\
\text { group }\end{array}$} & \multicolumn{2}{|c|}{$\begin{array}{l}\text { Control } \\
\text { group }\end{array}$} & \multirow{2}{*}{$\begin{array}{c}\text { Difference } \\
\%\end{array}$} & \multirow{2}{*}{$\begin{array}{l}\text { Standard } \\
\text { error of } \\
\text { difference }\end{array}$} \\
\hline No. & $\%$ & No. & $\%$ & & \\
\hline 29 & $16 \cdot 9$ & 40 & $23 \cdot 4$ & 6.5 & $4 \cdot 885$ \\
\hline 11 & $6 \cdot 4$ & 19 & $11 \cdot 2$ & $4 \cdot 8$ & $5 \cdot 458$ \\
\hline 6 & $3 \cdot 6$ & 3 & 1.8 & - & - \\
\hline 3 & 1.8 & 3 & $1 \cdot 8$ & - & 一 \\
\hline 12 & $7 \cdot 0$ & 7 & $4 \cdot 1$ & $2 \cdot 9$ & $2 \cdot 472$ \\
\hline - & - & - & - & - & 一 \\
\hline 4 & $2 \cdot 4$ & 3 & $1 \cdot 8$ & - & - \\
\hline 一 & - & 一 & - & - & - \\
\hline 2 & $1 \cdot 2$ & $\overline{-}$ & - & 一 & - \\
\hline 37 & $21 \cdot 7$ & 30 & $17 \cdot 6$ & $4 \cdot 1$ & $4 \cdot 457$ \\
\hline
\end{tabular}

(5) Certain important complications considered individually

The more important and frequent complications will now be considered individually in greater detail.

Table VIII. Cervical adenitis

\begin{tabular}{|c|c|c|c|c|c|c|}
\hline \multirow[b]{3}{*}{$\begin{array}{l}\text { Cervical adenitis present on } \\
\text { admission }\end{array}$} & \multicolumn{2}{|c|}{$\begin{array}{l}\text { Sulphanilamide } \\
\text { group }\end{array}$} & \multicolumn{2}{|c|}{$\begin{array}{l}\text { Control } \\
\text { group }\end{array}$} & \multirow{3}{*}{$\begin{array}{c}\text { Difference } \\
\% \\
7 \cdot 1\end{array}$} & \multirow{3}{*}{$\begin{array}{c}\text { Standard } \\
\text { error of } \\
\text { difference } \\
\end{array}$} \\
\hline & No. & $\%$ & No. & $\%$ & & \\
\hline & 108 & $63 \cdot 5$ & 96 & $56 \cdot 4$ & & \\
\hline Developed after admission & 19 & $11 \cdot 1$ & 19 & $11 \cdot 1$ & 一 & - \\
\hline $\begin{array}{l}\text { Present on admission and } \\
\text { had exacerbation later }\end{array}$ & 10 & $5 \cdot 8$ & 21 & $12 \cdot 3$ & $6 \cdot 5$ & $4 \cdot 885$ \\
\hline Total late cervical adenitis & 29 & $16 \cdot 9$ & 40 & $23 \cdot 4$ & $6 \cdot 5$ & $4 \cdot 885$ \\
\hline $\begin{array}{l}\text { Late cervical adenitis with } \\
\text { pyrexia }\end{array}$ & 6 & $3 \cdot 5$ & $14^{*}$ & $8 \cdot 2$ & $4 \cdot 7$ & $2 \cdot 411$ \\
\hline Suppurative adenitis & $1 \dagger$ & $0 \cdot 6$ & - & - & - & - \\
\hline $\begin{array}{l}\text { Small glands palpable on } \\
\text { dismissal }\end{array}$ & 49 & $28 \cdot 8$ & 50 & $29 \cdot 4$ & - & - \\
\hline
\end{tabular}
dismissal

* In two of these cases there was another complication which may have been a contributory cause of the pyrexia.

$\dagger$ This was a tuberculosis lesion, and the gland did not suppurate in the ordinary sense of the word.

Comment. Sulphanilamide did not appear to exercise any significant influence in reducing the incidence of late cervical adenitis. Although the actual incidence of late cervical adenitis was lower in the sulphanilamide group, the difference may have been due entirely to chance as the standard error is almost as great as the difference. 


\begin{tabular}{|c|c|c|c|c|c|c|}
\hline & \multicolumn{4}{|c|}{ Table IX. Rhinitis } & \multirow[b]{3}{*}{$\begin{array}{c}\text { Difference } \\
\%\end{array}$} & \multirow{3}{*}{$\begin{array}{l}\text { Standard } \\
\text { error of } \\
\text { difference }\end{array}$} \\
\hline & \multicolumn{2}{|c|}{ 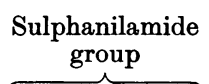 } & \multicolumn{2}{|c|}{$\begin{array}{l}\text { Control } \\
\text { group }\end{array}$} & & \\
\hline & No. & $\%$ & No. & $\%$ & & \\
\hline Present on admission & 32 & $18 \cdot 8$ & 31 & $18 \cdot 2$ & - & - \\
\hline Developed after admission & 11 & $6 \cdot 4$ & 19 & $11 \cdot 2$ & $4 \cdot 8$ & $5 \cdot 458$ \\
\hline \multirow{2}{*}{\multicolumn{7}{|c|}{$\begin{array}{l}\text { Total cases with rhinitis } \\
\text { Average duration in days after }\end{array}$}} \\
\hline & & & & & & \\
\hline Mean & \multicolumn{2}{|c|}{ 8.7* } & \multicolumn{2}{|c|}{$12.5 \dagger$} & - & - \\
\hline Median & \multirow{2}{*}{\multicolumn{2}{|c|}{4}} & \multirow{2}{*}{\multicolumn{2}{|c|}{$8 \cdot 5$}} & - & - \\
\hline Mode & & & & & - & - \\
\hline $\begin{array}{l}\text { Present till dismissal after } \\
\text { 8 weeks }\end{array}$ & 3 & 1.8 & - & - & - & - \\
\hline $\begin{array}{l}\text { Present till death } \\
\text { Average day of development } \\
\text { after admission: }\end{array}$ & 1 & $0 \cdot 6$ & - & - & - & - \\
\hline Mean & \multicolumn{2}{|c|}{$11 \cdot 2$} & & - & 一 \\
\hline Median & \multirow{2}{*}{\multicolumn{2}{|c|}{$\begin{array}{l}8 \\
5\end{array}$}} & \multirow{2}{*}{\multicolumn{2}{|c|}{$\begin{array}{l}16 \\
22 \ddagger\end{array}$}} & - & - \\
\hline Mode & & & & & - & - \\
\hline
\end{tabular}

* In 27 observed cases) In the remainder the disappearance of the discharge was gradual and $\dagger$ In 34 observed cases could not be defined with accuracy.

$\ddagger$ Three observations only.

Comment. Sulphanilamide appeared to exercise a slight effect in reducing the incidence of late rhinitis, but here again the difference between the two groups is statistically insignificant.

\section{Table X. Otitis media}

\begin{tabular}{|c|c|c|c|c|}
\hline & \multicolumn{2}{|c|}{ Sulphanilamide group } & \multicolumn{2}{|c|}{ Control group } \\
\hline & No. & $\%$ & No. & $\%$ \\
\hline Total cases & 7 & $4 \cdot 1$ & 8 & $4 \cdot 6$ \\
\hline Present on admission & 1 & 0.6 & 5 & $2 \cdot 9$ \\
\hline Developed after admission & 6 & $3 \cdot 6$ & 3 & $1 \cdot 8$ \\
\hline $\begin{array}{l}\text { Mean number of days in hospital } \\
\text { when otitis developed }\end{array}$ & \multirow{2}{*}{\multicolumn{2}{|c|}{$15 \cdot 3$}} & \multirow{2}{*}{\multicolumn{2}{|c|}{$15 \cdot 3$}} \\
\hline $\begin{array}{l}\text { Average duration in days after } \\
\text { admission or development: }\end{array}$ & & & & \\
\hline Mean & \multicolumn{2}{|c|}{$23 \cdot 5$} & \multicolumn{2}{|c|}{$22 \cdot 6$} \\
\hline Median & \multirow{2}{*}{\multicolumn{2}{|c|}{$\begin{array}{l}16 \\
28 \cdot 7\end{array}$}} & \multicolumn{2}{|c|}{17} \\
\hline $\begin{array}{l}\text { Mean duration in days of residence } \\
\text { in hospital }\end{array}$ & & & & \\
\hline
\end{tabular}

Comment. Sulphanilamide appeared to have no effect in diminishing the incidence or duration of otitis media. This was disappointing. It was thought that the drug might be particularly effective in dealing with such complications of scarlet fever as are of a septic nature, e.g. otitis media, and would lead to a diminution in their incidence and lessen their duration. In the cases observed sulphanilamide did neither, and better results as regards both incidence and duration of otitis media were obtained in the control group.

\section{Table XI. Late albuminuria}

\begin{tabular}{|c|c|c|c|c|c|c|}
\hline & \multicolumn{2}{|c|}{$\begin{array}{c}\text { Sulphanilamide } \\
\text { group }\end{array}$} & \multicolumn{2}{|c|}{ group } & \multirow{2}{*}{$\begin{array}{l}\text { Difference } \\
\%\end{array}$} & \multirow{2}{*}{$\begin{array}{l}\text { Standard } \\
\text { error of } \\
\text { difference }\end{array}$} \\
\hline & No. & $\%$ & No. & $\%$ & & \\
\hline Total cases & 12 & $7 \cdot 0$ & 7 & $4 \cdot 1$ & $2 \cdot 9$ & $2 \cdot 455$ \\
\hline $\begin{array}{l}\text { Mean day of occurrence } \\
\text { Average duration in days: }\end{array}$ & \multicolumn{2}{|c|}{$11 \cdot 6$} & \multicolumn{2}{|r|}{$18 \cdot 4$} & - & - \\
\hline Mean & \multirow{2}{*}{\multicolumn{2}{|c|}{$\begin{array}{l}4 \cdot 2 \\
1\end{array}$}} & \multirow{2}{*}{\multicolumn{2}{|c|}{$\begin{array}{l}2 \cdot 4 \\
1\end{array}$}} & - & - \\
\hline Mode & & & & & - & - \\
\hline $\begin{array}{l}\text { Mean duration in days of } \\
\text { residence in hospital }\end{array}$ & \multicolumn{2}{|c|}{$30 \cdot 2$} & \multicolumn{2}{|r|}{$36 \cdot 8$} & - & - \\
\hline
\end{tabular}

Comment. Sulphanilamide seemed to have no influence in diminishing the incidence or duration of late albuminuria. 
Other complications. As far as could be judged, sulphanilamide had no effect in preventing the onset or curtailing the duration of other complications - septic or otherwise. The total incidence of these minor complications was low, and I think that in any one case their origin could be attributed almost entirely to chance.

(6) The effect of sulphanilamide on the complication rate of cases admitted to hospital on the 4 th day of illness or later

\begin{tabular}{|c|c|c|c|c|c|c|}
\hline & & able X & & & & \\
\hline & Sulph & $\begin{array}{l}\text { ilamide } \\
\text { up }\end{array}$ & & & & \\
\hline & No. & $\%$ & No. & $\%$ & $\%$ & difference \\
\hline Cases admitted from 4th day on & 28 & $100 \cdot 0$ & 33 & $100 \cdot 0$ & - & - \\
\hline $\begin{array}{l}\text { Cases with no complications at } \\
\text { any time }\end{array}$ & 2 & $7 \cdot 1$ & 7 & $21 \cdot 2$ & $14 \cdot 1$ & 8.993 \\
\hline $\begin{array}{l}\text { Complications: } \\
\text { (A) Present on admission: }\end{array}$ & & & & & & \\
\hline Cervical adenitis & 19 & 67.8 & 15 & $45 \cdot 3$ & - & - \\
\hline Rhinitis & 5 & $17 \cdot 8$ & 5 & $15 \cdot 1$ & - & - \\
\hline Otitis media & 1 & 3.5 & - & - & - & - \\
\hline Albuminuria & 1 & 3.5 & - & - & - & - \\
\hline Other & 5 & $17 \cdot 8$ & 4 & $12 \cdot 1$ & - & - \\
\hline $\begin{array}{l}\text { (B) Developed after admission: } \\
\text { Cervical adenitis }\end{array}$ & ? & 7.1 & 5 & 15.1 & & \\
\hline $\begin{array}{l}\text { Cervical adenitis } \\
\text { Rhinitis }\end{array}$ & 4 & $14 \cdot 2$ & 3 & 9.0 & E & 二 \\
\hline Otitis media & 3 & $10 \cdot 7$ & 1 & 3.0 & - & - \\
\hline Albuminuria & 3 & $10 \cdot 7$ & 4 & $12 \cdot 1$ & - & - \\
\hline Secondary tonsillitis & 2 & $7 \cdot 1$ & - & - & - & - \\
\hline Other & 8 & 28.5 & 7 & $21 \cdot 2$ & - & - \\
\hline
\end{tabular}

Comment. Most authorities consider that serum has relatively little value in scarlet fever if given later than the 3rd day of illness. It might, therefore, be expected that sulphanilamide would have some value in the treatment of cases admitted to hospital after the 3rd day. As the foregoing figures show sulphanilamide had no effect whatsoever in reducing the incidence of complications in such cases-the incidence of most complications being in fact lower in the control group.

\section{The Mortality OF THE SERIES}

There was one death in 340 cases-a fatality rate of $0 \cdot 6 \%$. The case was in the sulphanilamide group. There were several factors militating against recovery in this instance, and the failure of sulphanilamide to prevent a fatal result is perhaps scarcely remarkable. Nevertheless, it is noteworthy that although the drug was administered from the first day of illness it did not prevent the development of several septic complications.

Case history. C. C. Female, aged 4 years. This child suffered from advanced and active Still's disease. She was admitted on the first day of what appeared to be a very mild attack of scarlet fever. Slight cervical adenitis was the only complication then present. On the 4th day of illness she developed purulent rhinitis, and on the 5th bilateral acute otitis media. There was now a recurrence of the rash. On the 16th day there appeared signs of consolidation in lower lobe of the right lung. Otitis and rhinitis continued. She died on the 19th day of illness. Permission for post-mortem examination was not obtained. Serum was not given at the beginning as the case seemed so mild and because of its possible adverse effect on the joints. When the rash recurred on the 5 th day, 20 c.c. were given intramuscularly, and 5 days 
later there was a very severe serum reaction. On the 16 th day of illness 90 c.c. polyvalent antistreptococcal serum was given per rectum, and 20 c.c. scarlet fever antitoxin intramuscularly, in the vain hope that the child's condition might be improved thereby.

\section{COMPARISON OF THE THERAPEUTIC ACTIVITY OF SULPHANILAMIDE AND BENZYL-SULPHANILAMIDE}

The results of treatment with sulphanilamide and benzyl-sulphanilamide were analysed separately but no statistically significant differences were shown, and the figures are not therefore published.

\section{The TOXIC EFFeCtS OF SUlPhaNilamide}

A considerable number of the patients treated with sulphanilamide and with benzyl-sulphanilamide showed unpleasant reactions which were considered to be due to the drug. The more important of these were cyanosis and rashes. Two other serious conditions occurred which may have been due to sulphanilamide, i.e. a degenerative nephritic lesion, and anaemia. The more frequently observed toxic effects will now be described more fully and the other two lesions will be shortly discussed.

(a) Cyanosis. This occurred in seventeen cases, i.e. $10 \%$ of 170 . It showed itself as a faint bluish tinge of the lips, and occasionally the patients had "dark circles" under the eyes. It tended to disappear spontaneously even when administration of the drug was continued, and, in fact, administration was only stopped in one case on the appearance of cyanosis. Although no spectroscopic examinations were made it is reasonable to assume that in no case was cyanosis due to sulphaemoglobinaemia.

The mean age incidence of cases showing cyanosis was $6 \cdot 1$ years. The mean amount of drug taken before the occurrence of cyanosis was $31.3 \mathrm{~g}$., and the mean day of treatment on which cyanosis was noted was $9 \cdot 6$, the earliest the $2 \mathrm{nd}$, and the latest the 23rd. The mean duration in days was $2 \cdot 1$, the mode 1 day, and the longest duration 10 days. In two cases it was associated with a slight pyrexia, but there was no other constitutional disturbance.

(b) Drug rashes. Nineteen patients ( $=11.5 \%$ of 170$)$ showed drug rashes and in seventeen $(=10 \%$ of 170 , and $89.4 \%$ of 19$)$ they were associated with pyrexia. The general type of rash and reaction conformed to that described by other writers, but a point of difficulty arose in my cases because many of them occurred in patients who were treated with serum, in whom, therefore, a serum reaction might have occurred about the same time as the sulphanilamide reaction. It was found that the sulphanilamide rash was never itchy unless in patients who had had serum. Consequently in all cases in which the rash was itchy it was considered that serum was partly responsible for its production. On the other hand serum could not have been held wholly responsible, as the rash was morphologically different from that commonly encountered in serum reactions, and these variations in the form of the serum rash never occurred 
except in patients who had received sulphanilamide. Furthermore, the rash occurred in several patients who had not received serum.

The characteristic sulphanilamide rash is erythematous and maculopapular. It reaches its maximum intensity quickly, discrete spots giving place in a few hours to confluent macules. It is almost always present on the face and forehead, and on the limbs. In the latter situation it shows a very distinct tendency to attack the exterior surfaces especially in the neighbourhood of the knees and elbows. The buttocks are usually involved but the trunk sometimes escapes. The rash fades fairly quickly, and is not followed by desquamation or staining.

Most writers have described the sulphanilamide rash as "morbilliform". I think that it is more often rubelliform. In only two of my cases did the rash look like a measles rash. Certainly in the early stages at least, it very closely resembles rubella, but in colour it is distinctly darker than rubella, and confusion with the rash of scarlet fever is unlikely to occur. The resemblance to rubella is increased by the fact that in a considerable proportion of cases the rash is accompanied by enlargement of the posterior cervical glands. I do not know why this occurs.

The rash was urticarial in character only in cases whicb had received serum, and even in these the erythematopapular character was only modified, and not concealed. No haemorrhagic rashes were seen. Exposure to sunlight did not appear to play any part in the production of a rash. The rash was usually accompanied by slight pyrexia, but the patients suffered very little general disturbance, and never complained of feeling ill, even in response to a leading question on this subject. No difference was observed in the rashes produced by sulphanilamide and benzyl-sulphanilamide.

The mean amount of sulphanilamide taken before the occurrence of a reaction was $46 \cdot 1 \mathrm{~g}$. The mean day of appearance of the reaction was $10 \cdot 6$, the mode $10 \cdot 5$, the earliest 9 , and the latest 13 . The mean age incidence was 8 years. The mean duration in days of the rash was $2 \cdot 6$, the mode 1.5 and the longest 6 . The mean duration in days of pyrexia associated with a rash $2 \cdot 3$, the mode 2 , and the longest 5 . In ten cases the rash was itchy (all these cases had received serum). Posterior cervical adenitis was present in six cases.

(c) Degenerative nephritis. It is submitted that not only does sulphanilamide fail to prevent the occurrence of renal damage in scarlet fever, but that it may even be a cause of it, as the following case history suggests.

Case history. M. M. Female, aged 6 years. No previous illnesses. Admitted on 3rd day of a severe attack of scarlatina simplex. Given 20 c.c. serum and routine sulphanilamide treatment. For 14 days there was continuous pyrexia, and the throat was in a very foul condition. On the 14th day of illness there was a generalized itchy rubelliform rash and sulphanilamide was discontinued. On the 20 th day there appeared gross albuminuria, with much oedema and some ascites. B.P. $140 / 110 \mathrm{~mm}$. $\mathrm{Hg}$. These symptoms continued for about a week and then gradually abated, the urine being free from albumin on the 35th day of illness. A week later the child had a small septic abrasion of the ear and albuminuria 
recurred. Slight albuminuria persisted, and she was finally sent home under the care of her own doctor, at the end of the 8th week of illness.

There was no blood in the urine at any time, either macroscopically or microscopically. During the acute stage of the nephritis very numerous epithelial casts were present.

What was the nature of this renal lesion, and what its cause? This case did not conform to the usual type of acute scarlatinal nephritis, which, indeed, is the modal form for acute glomerulo-nephritis, with blood and albumin conspicuously present in the urine. $\operatorname{Ker}$ (1929) states that in scarlatinal nephritis the urine "usually but not always, contains blood", Goodall \& Washbourn (1929) that "blood is usually present", while Rolleston (1929) makes no mention of scarlatinal nephritis without haematuria. It would appear therefore that the lesion of this case was not the usual scarlatinal glomerulo-nephritis, but was a degenerative type of lesion, affecting more the tubules than the glomerular tufts. This type of lesion owes its origin to various toxins, and to certain drugs and chemicals (Muir, 1936), and I think that it is possible that sulphanilamide may have been the cause in this case. The patient earlier had shown signs of intolerance to that drug, and though it is probable that all the sulphanilamide had been excreted before the nephritis appeared, the possibility that it exercised a delayed toxic action cannot be absolutely excluded.

Colebrook \& Kenny (1936) found that in patients treated with drugs of the sulphanilamide class, $75 \%$ had shed epithelial cells in the urine, $40 \%$ passed red blood cells, and a few of these casts. Of all their patients, $20 \%$ either developed a trace of albumin in the urine during treatment, or showed an increase in albuminuria that had been present before. Foulis \& Barr (1937) found that out of 22 patients treated with sulphanilamide two developed albuminuria, which they attributed to a toxic action of the drug. Therefore the contention that sulphanilamide may be a cause of renal damage is not a new one.

It is also possible that this child's kidneys had previously suffered some damage, and scarlet fever had merely lit up a latent lesion. I was unable, however, to obtain a history of any previous illness from the patient's mother who was an intelligent woman. It is, therefore, unlikely that such a lesion existed.

The potential causes of the condition seem to be three: (1) scarlet fever, (2) sulphanilamide, (3) a combination of scarlet fever and sulphanilamide. One cannot be more exact as to the pathogenesis.

(d) Anaemia. Sulphanilamide seemed to exert a depressant effect on the leucocyte count (French, 1939), and one patient developed anaemia, with lymphocytosis, which appeared to be due to the drug, which in this case may also have exercised a toxic action on the myocardium.

Case history. L. G. Female, aged 11 years. Admitted on 3rd day of a very mild attack of scarlatina simplex. No serum given. Routine sulphanilamide treatment. On the 10th day of treatment she had pyrexia, a widespread rubelliform rash and generalized adenitis. The possibility of sulphanilamide as the cause of this patient's rash was not recognized at the time (the diagnosis was rubella), and the drug was continued for the full period of 28 days. The day after the drug was discontinued she was found to have a fairly marked secondary anaemia, with lymphocytosis, and it is very difficult to believe that sulphanilamide was not the cause of this. Unfortunately, no blood counts were done on admission or early in her illness, but she was then a child of rather high colour, in whom there was not the slightest reason to suspect anaemia. From the 31st day to the 38th day of illness the pulse was infrequent and irregular due to occasional dropped beats. The heart sounds were of poor quality. From the 32nd day of illness onwards, a soft systolic murmur was audible at the pulmonic area, where the second sound was exaggerated. It seems very likely that in this case sulphanilamide exercised a toxic action on the myocardium-the original attack of scarlet fever was so mild that it is improbable that it was concerned in the pathogenesis of the heart 
lesion. No cause was found for the pyrexia in the 4th week of illness-probably this was "drug fever".

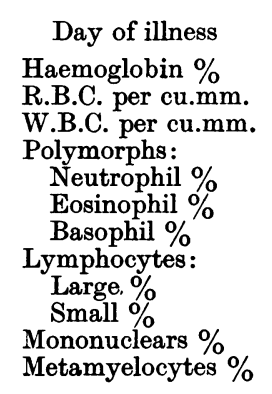

\section{Table XIII. Blood counts}

32
66
$3,670,000$
12,400
40
$1 \cdot 5$
$0 \cdot 5$
$17 \cdot 5$
31
8
$1 \cdot 5$

$\begin{array}{cc}34 & 36 \\ 78 & 73 \\ 4,270,000 & 3,650,000 \\ 10,400 & 9,100 \\ 59 \cdot 5 & 63 \cdot 5 \\ 1 & 1 \\ 0 \cdot 5 & 0 \cdot 5 \\ 9 \cdot 5 & 6 \\ 25 & 23 \cdot 5 \\ 3 & 4 \cdot 5 \\ 1 & 1\end{array}$

\section{Discussion}

Judging by the evidence presented, sulphanilamide and benzyl-sulphanilamide are ineffective in the treatment of scarlet fever. The possible causes of this therapeutic failure will be briefly discussed.

Okell (1932) showed that the streptococcus has three main toxic effects: (i) due to the haemolysing toxin, (ii) due to the rash-producing toxin, and (iii) due to invasiveness or pyogenicity. In scarlet fever the first has little effect except in the very toxic case, the second is extremely effective, and the third may be said to be selective and to be seen in certain cases, e.g. septic scarlet fever. Scarlet fever antitoxin is effective against the rash-producing toxin, and indirectly against such complications as are believed to be a late result of that toxin, e.g. nephritis and albuminuria, myocarditis, endocarditis, and arthritis. Upon these, therefore, sulphanilamide could not be presumed to have much effect, and in the cases investigated it did not do so.

From animal experiments and erysipelas work it can be said that sulphanilamide is effective against invasiveness. If scarlet fever antitoxin is given late, or if the streptococcus is particularly invasive, rhinitis, otitis, albuminuria and nephritis, and cervical adenitis may still be troublesome, and in such cases sulphanilamide might be expected to be of value. The combination of sulphanilamide and antitoxin can only have effect on the occurrence of such complications as may be considered to be due to the invasive character of the streptococcus. If sulphanilamide is effective it might be expected to lead to a diminution in their incidence, or, if they have already occurred, to lessen their intensity and curtail their duration. I have not been able to show that such is the action of sulphanilamide.

To what factor or factors can the failure of sulphanilamide to lower the incidence and diminish the duration of septic complications be attributed? Four possible answers to this question suggest themselves:

(1) The substances used were not potent. It is extremely unlikely that this was so. The drugs used were all manufactured by firms of repute, and have many times proved their efficacy in the hands of other workers. 
(2) The dosage used was insufficient. This also is most unlikely. The dose employed was much larger than that used by most other workers, and in my cases therapy was continued over a far longer period. This hypothesis, therefore, may be dismissed as untenable.

(3) The infecting streptococcus was of too low virulence to be affected by sulphanilamide. Colebrook \& Kenny (1936) found that sulphanilamide had very little effect upon strains of haemolytic streptococci of low mouse virulence. This was confirmed by Long \& Bliss (1937), but not by Mellon, Gross \& Cooper (1937). At present this question seems to be undecided. However, even admitting that sulphanilamide is not effective against haemolytic streptococci of low virulence, there is little evidence to show that its failure in the present series of cases was due to the fact that the infecting organism was lacking in virulence. Although the more serious complications of scarlet fever were conspicuously absent from these cases, the total incidence of complications was high, and in respect of its capability for producing these complications the strain of streptococcus involved must be judged to have possessed at least average virulence.

(4) Does the erythrogenic toxin in some way interfere with the action of sulphanilamide in vivo? This is a pure speculation, and, as far as I know, has not been suggested by any experimental work. There appear to be grounds for the speculation, because sulphanilamide has been effective in most $\beta$-haemolytic streptococcal infections with the single exception of scarlet fever. The chief point that distinguishes scarlet fever from these other infections is the rash-in other words the susceptibility of the patient to the erythrogenic toxin of the streptococcus. On the whole, it is rather unlikely that the erythrogenic toxin does interfere with the action of sulphanilamide, because the Dick Test has shown that in almost $100 \%$ of cases immunity to the erythrogenic toxin has been produced after the first few days of scarlet fever, certainly within a week of the onset of the disease. Consequently, after that period any interference with the action of sulphanilamide should be ended, and the drug should be as efficacious as in other streptococcal infections. Nevertheless, in the series of cases described the time incidence of two later septic complications, namely rhinitis and otitis media, was found on the average to be well after the first week of illness, the mean days of onset being $11 \cdot 2$ and $15 \cdot 3$ respectively in those cases that were treated with sulphanilamide.

None of these hypotheses, therefore, explain the therapeutic inefficacy of sulphanilamide in scarlet fever.

Another interesting and disappointing feature of the action of sulphanilamide in scarlet fever was its relatively great liability to produce toxic effects, which were noted in $21.1 \%$ of treated cases. It is certain that these reactions occur in a large proportion of patients treated with sulphanilamide. Though the reactions met with in the series of cases here described were mostly comparatively trivial, it must be remembered that serious and even fatal results have followed the use of sulphanilamide and benzyl-sulphanilamide. 
Bearing all these facts in mind, I believe that there is no justification for the employment of sulphanilamide and benzyl-sulphanilamide in scarlet fever. I am not unmindful of the fact that dramatic cures of some of the more serious complications of scarlet fever have been recorded following their use. Reports based on a few isolated and selected cases of a disease which is notoriously so variable in the severity of its manifestations have little scientific value, and should not be used as evidence of the efficacy of a new therapeutic agent.

\section{SUMMARY AND CONCLUSIONS}

1. A series of 340 cases of scarlet fever was treated under controlled conditions, $(a)$ with sulphanilamide or benzyl-sulphanilamide, and $(b)$ without sulphanilamide.

2. There was an even distribution of the individual cases in respect of factors known to influence the course of the disease, such as $(a)$ the duration of the disease before admission to hospital, and $(b)$ the severity of the infection.

3. Treatment was carried out during the whole period of 4 weeks, which constitutes the average period of hospitalization in scarlet fever.

4. The dose employed was large: $(a)$ patients 5 years of age and over receiving 1 g. 4 hourly (i.e. 5 g. a day) for the first 14 days in hospital, thereafter 1 g. t.i.d. (i.e. $3 \mathrm{~g}$. a day) for 14 days; a maximum total dose of $112 \mathrm{~g}$., and $(b)$ patients under 5 years of age receiving 0.5 g. 4 hourly (i.e. 2.5 g. a day) for the first 14 days in hospital, thereafter 0.5 g., t.i.d. (i.e. 1.5 g. a day) for 14 days; a maximum total dosage of $56 \mathrm{~g}$.

5. The results show that sulphanilamide had no significant effect upon the initial symptoms of scarlet fever, or upon the kind, incidence, or duration of later complications.

6. A large number of toxic reactions followed the use of both sulphanilamide and benzyl-sulphanilamide.

7. In view of all the evidence submitted, it is considered that there is no justification for the employment of sulphanilamide and benzyl-sulphanilamide in the treatment of scarlet fever.

I am greatly indebted to Dr W. M. Elliott, Physician-Superintendent, Ruchill Fever Hospital, Glasgow, for permission to publish the results of this investigation.

\section{REFERENCES}

Basman, J. \& Perley, A. M. (1937). J. Pediat. 11, 212.

Colebrook, L. \& Kenny, M. (1936). Lancet, 1, 1279.

Foulis, M. A. \& BARR, J. B. (1937). Brit. med. J. 1, 445.

French, J. O. (1939). Lancet, 2, p. 127.

Goodall, E. W. \& Washbourn, J. W. (1929). Infectious Diseases, 3rd ed. pp. 221 et seq.

H. K. Lewis and Co. Ltd.

HaGeMAN, P. O. \& Blake, F. G. (1938). Amer. J. med. Sci. 195, 163.

Hogarth, J. C. (1937). Brit. Med. J. 2, 1160. 
KeR, C. B. (1929). Infectious Diseases, 3rd ed. pp. 83 et seq. Oxford Univ. Press. Long, P. H. \& Bliss, E. A. (1937). J. Amer. med. Ass. 108, 32.

McIntosh, R., Wilcox, D. A. \& Wright, F. H. (1937). J. Pediat. 11, 167.

Mellon, R. R., Gross, P. \& Cooper, F. B. (1937). J. Amer. med. Ass. 108, 1858.

Mitchell, A. G. \& Trachsler, W. H. (1937). J. Pediat. 11, 183.

Murr, R. (1936). Text-book of Pathology, 4th ed. p. 675. Edward Arnold and Co.

Okell, C. C. (1932). Lancet, 1, 761, 815, 867.

Osqood, E. E. \& Brownlie, I. E. (1938). J. Amer. med. Ass. 110, 348.

Patterson, D. C. (1937). J. Conn. St. Med. Ass. 1, 358.

Peters, B. A. \& Havard, R. V. (1937). Lancet, 1, 1273.

Rolleston, J. D. (1929). Acute Infectious Diseases, 2nd ed. pp. 251 et seq. Wm. Heinemann, Ltd.

Sako, W., Dwan, P. F. \& Platou, E. S. (1938). J. Amer. med. Ass. 110, 995.

(MS. received for publication 12 . vir. $39-\mathrm{Ed}$.) 